\title{
The life cycle of Sphaerospora truttae (Myxozoa: Myxosporea) and some features of the biology of both the actinosporean and myxosporean stages
}

\author{
A. Özer ${ }^{1,2}$, R. Wootten ${ }^{1, *}$ \\ ${ }^{1}$ University of Stirling, Institute of Aquaculture, Stirling FK9 4LA, Scolland, UK \\ ${ }^{2}$ Ondokuzmayis Üniversitesi, Su Ürünleri Fakültesi, 57000 Sinop, Turkey
}

\begin{abstract}
A previously undescribed echinactinomyxon type actinosporean was shown experimentally to be the alternate stage of Sphaerospora truttae. The echinactinomyxon type spores were found to be released from Lumbriculus variegatus and occasionally Tubifex tubifex. Overall infection prevalence of the echinactinomyxon was $0.14 \%$. Peak release was in March-May each year $S$. truttae spores developed in experimentally infected salmon 4.5 mo post-exposure to echinactinomyxon spores. Extrasporogonic stages of $S$. truttae first appeared in naturally infected salmon in early July and persisted for 8 to $10 \mathrm{wk}$. Correlation between peak release of echinactinomyxon spores and appearance of extrasporogonic stages of $S$. truttae is discussed.
\end{abstract}

KEY WORDS: Sphaerospora truttae $\cdot$ Life cycle $\cdot$ Actinosporean $\cdot$ Myxosporean

\section{INTRODUCTION}

The life cycles of 17 different myxosporean species belonging to 7 different genera (Myxobolus, Thelohanellus, Myxidium, Zschokkella, Ceratomyxa, Hoferellus and Sphaerospora) have been completed and shown to involve members of 7 collective groups of actinosporeans (triactinomyxon, hexactinomyxon, raabeia, aurantiactinomyxon, neoactinomyxum, guyenotia and siedleckiella) (Markiw \& Wolf 1983, ElMatbouli \& Hoffmann 1989, 1993, Rudish et al. 1991, Styer et al. 1991, El-Matbouli et al. 1992, Grossheider \& Körting 1992, Benajiba \& Marques 1993, Kent et al. 1993, Uspenskaya 1995, Yokoyama et al. 1995, Troullier et al. 1996, Bartholomew et al. 1997, Yokoyama 1997. El-Mansy et al. 1998a,b,c, Szekely et al. 1998, Molnar et al. 1999). So far only 2 Sphaerospora species, $S$. ictaluri and $S$. renicola, have been shown to have an alternate actinosporean stage, with an aurantiactinomyxon and neoactinomyxum type, from the oligochaetes Dero digitata and Branchiura sowerbyi, respectively (Styer et al. 1991, Molnar et al. 1999).

•Corresponding author. E-mail: r.wootten@stir.ac.uk
Sphaerospora truttae was first described by FischerScherl et al. (1986) from brown trout Salmo trutta L in Germany. Since then, Walter et al. (1991) and McGeorge et al. (1996a,b) reported this parasite from grayling Thymallus thymallus L. in Germany and Atlantic salmon Salmo salar L. in Scotland, respectively. The latter authors conducted extensive studies on its morphology, ultrastructure and biology.

McGeorge et al. (1996a) showed that Sphaerospora truttae has 2 distinct stages, extrasporogonic and sporogonic, in fish. The first detectable signs of infection occurred each year in late June/early July in fish when extrasporogonic stages were found in the blood and kidney interstitium. These stages were present until early September and the sporogonic stages occurred in the kidney tubules from early August, with mature spores first being present in September ( $M C$ George et al. 1996a). They also showed that the temperature was an important factor influencing the infection prevalence and intensity of $S$. truttae.

In the present study, the life cycle of Sphaerospora truttae was completed using echinactinomyxon type actinospores and the biology of both the actinosporean and myxosporean stages of $S$. truttae were studied, 
particularly in relation to the seasonal pattern of release of echinactinomyxon spores and the infection of salmon with S. truttae.

\section{MATERIALS AND METHODS}

Sampling programme. Fish and oligochaete samples were collected from a freshwater Atlantic salmon farm located in Northern Scotland (British National Grid NC 387546). This was the same site used by McGeorge et al. (1997). Sampling

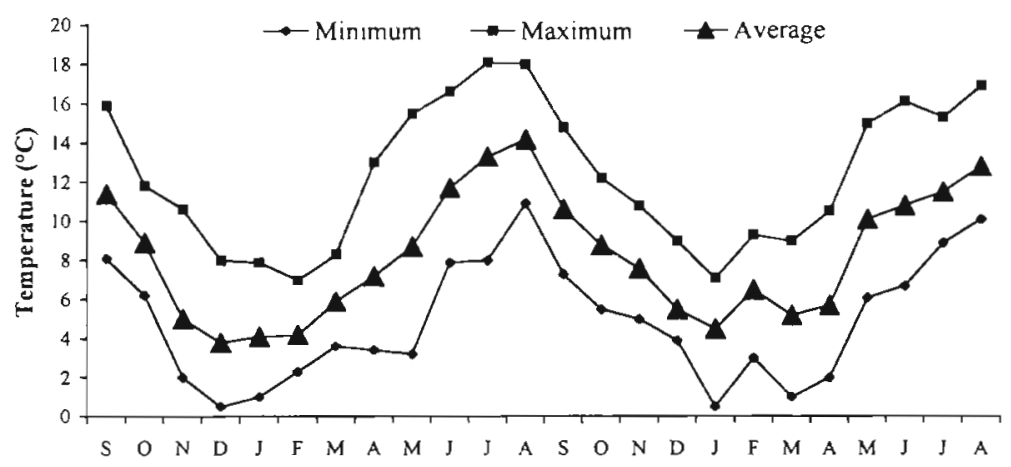

Fig. 1. Monthly minimum, maximum and average water temperatures $\left({ }^{\circ} \mathrm{C}\right)$ at the salmon farm was carried out at intervals of $4 \mathrm{wk}$ in spring and summer and 6 wk in autumn and winter. Whilst oligochaete sampling took place from 17 October 1996 to 16 August 1998, fish samples were collected from 17 October 1996 to 6 September 1997 on the same day that oligochaetes were collected.

Sampling procedure for oligochaetes. Oligochaetes were collected from a settlement pond located at the downstream end of the farm. Oligochaetes were separated from substrate by passing the sediment through graded sieves of $1.5 \mathrm{~mm}, 1 \mathrm{~mm}$ and $500 \mu \mathrm{m}$ mesh size. The contents of the sieves were then emptied into shallow basins containing dechlorinated tap water and observed under bright light to detect oligochaetes. At least 1000 worms were obtained at each sampling time. Oligochaetes were identified according to the key of Brinkhurst (1963).

Sampling procedure for fish. Fish were randomly netted on each sampling date from the same tank cohort of fish as far as possible. When the population was graded, one of the resulting populations was sampled. At least 20 fish were collected at each sampling date. All fish samples were transferred alive to the Institute of Aquaculture, Stirling, in oxygenated river water.

Actinosporean samples. Actinosporean spores were collected from infected oligochaetes kept in 24-cell well plates according to the method of Yokoyama et al. (1991) and examined under an inverted microscope after $24 \mathrm{~h}$.

Farm water temperature. Daily farm temperature data was collected from the records of the fish farm and plotted monthly with minimum, maximum and average levels (Fig, 1). Strict seasonal patterns were observed each year, with a maximum of $18^{\circ} \mathrm{C}$ in JulyAugust and a minimum of $1^{\circ} \mathrm{C}$ in December-January.

Identification of actinosporean types released. Released actinosporeans were drawn and photographed under both phase contrast and bright field. Measurements were taken from at least 20 randomly selected spores from 1 infected oligochaete where possible, using a micrometer calibrated eye-piece graticule Dead, senescent or immature spores were not used for measurement. Spores were identified using the keys and diagrams of Janiszewska $(1955,1957)$, Marques (1984), Lom et al. (1997) and by comparison with other published reports. The echinactinomyxon stage spore of Sphaerospora truttae was designated as echinactinomyxon types in Özer (1999).

Experimental fish. Juvenile Atlantic salmon (length 10 to $13 \mathrm{~cm}$ ) were collected from a farm where fish were reared entirely on bore-hole water. In the laboratory fish were kept in $100 \mathrm{l}$ rectangular tanks supplied with charcoal filtered mains water at 12 to $16^{\circ} \mathrm{C}$ and fed ad libitum with a commercial pelleted feed. Thirty fish were sacrificed and examined for the presence of myxosporean infection by the methods outlined below.

Exposure of fish to actinosporean spores. In transmission experiments using actinosporean spores, the water level of aquaria $(13 \times 12 \times 21 \mathrm{~cm})$ was reduced to $1-2 \mathrm{l}$ with no aeration for $30 \mathrm{~min}$ to $1 \mathrm{~h}$. Echinactinomyxon type spores were pipetted into the tanks at the beginning of this period. Where sufficient spores were available, the exposure of fish to echinactinomyxon type spores was repeated on up to 3 subsequent days. After $1 \mathrm{~h}$, fish and unexposed control fish were transferred to aquaria containing charcoal filtered mains water for 3.5 to $4.5 \mathrm{mo}$. After $3.5 \mathrm{mo}$, half the number of infected and control fish were individually examined as described below for the presence of myxosporean spores. Remaining fish were examined after $4.5 \mathrm{mo}$.

Examination of fish for myxosporeans. Fish were sacrificed by means of a sharp blow to the head. In fish from the salmon farm blood was obtained from the caudal artery by severing the tail and at least 3 blood smears were made from each fish and stained with a Rapi-Diff II staining kit (Lamb, London, UK). The body cavity was dissected and the liver, heart, kidney, digestive tract, gall bladder, swimbladder, urinary bladder, reproductive organs and brain removed for further 
examination. All the organs used for detection of myxosporeans were examined using squash preparations. Kidneys were examined by squash preparations or Rapi-Diff II stained impression smears of anterior, mid and posterior kidney. Squash preparations were examined using standard light, phase contrast and Nomarski optics.

Fish from experimental infections, including control fish were examined as described above except that blood was not examined.

Experimental exposure of fish to actinosporeans. Expt 1: Six Atlantic salmon were exposed to echinactinomyxon type spores for 3 d starting 29 March 1997 at a concentration of 10000 to 12000 spores fish $^{-1}$ $\mathrm{d}^{-1}$. Six Atlantic salmon were used as a control.

Expt 2: Four Atlantic salmon were exposed to echinactinomyxon type spores for $2 \mathrm{~d}$ starting on 9 August 1997 at a concentration of 10000 to 15000 spores fish $^{-1}$ $\mathrm{d}^{-1}$. Four Atlantic salmon were used as a control.

\section{RESULTS}

\section{Experimental infection of fish}

Thirty fish sampled from the stock of experimental fish prior to infection experiments were uninfected with myxosporeans. The control fish from both experiments (Expts 1 and 2) were also negative for myxosporean infections at the termination of the relevant experiment

\section{Expts 1 and 2}

Combining the results of both experiments, a total of 5 fish out of 10 were found infected with sporogonic stages of Sphaerospora truttae after $3.5 \mathrm{mo}(110 \mathrm{~d})$ and with mature spores of $S$. truttae in the tubule lumen of the infected salmon after 4.5 mo (138 d) (Table 1).

Myxosporean stage spores $(n=20)$ of Sphaerospora truttae obtained from the kidney tubules of experimentally infected salmon after $138 \mathrm{~d}$ were $7.57 \mu \mathrm{m}$ (6.75 to $8.00)$ in length and $10.10 \mu \mathrm{m}(9.30$ to 11.15$)$ in width. The polar capsules were $2.45 \mu \mathrm{m}(2.10$ to 3.00$)$ in diameter (Fig. 2b,c).

\section{Description of echinactinomyxon type spores}

The echinactinomyxon stage spores $(n=20)$ of Sphaerospora truttae had a spore body with 3 very elongated and remarkable polar capsules which occupied nearly the half of the epispore cavity. Caudal processes were straight but curved at the distal end
Table 1. Sphaerospora truttae infections in Atlantic salmon experimentally exposed to spores of echinactinomyxon

\begin{tabular}{|lcc|}
\hline Months post-infection & Sample size & No. of fish infected \\
\hline Expt 1 & & \\
Experimental group & 3 & 2 (sporogonic stages) \\
3.5 mo & 3 & 1 (mature spores) \\
4.5 mo & & \\
Control group & 3 & 0 \\
3.5 mo & 3 & 0 \\
4.5 mo & & \\
Expt 2 & & \\
Experimental group & 2 & 2 (sporogonic stages) \\
3.5 mo & 2 & 0 \\
4.5 mo & & 0 \\
Control group & 2 & 0 \\
3.5 mo & 2 & \\
4.5 mo & & \\
\hline
\end{tabular}

(Figs. 2a \& 3). The spore body was 11.2 (10 to 12$) \mu \mathrm{m}$ in length and 8.1 ( 7 to 9) $\mu \mathrm{m}$ in width. Polar capsules were 5 by $2 \mu \mathrm{m}$. The length of the caudal processes was 58 (38 to 75 ) $\mu \mathrm{m}$.

\section{Prevalence rate of the echinactinomyxon stage of Sphaerospora truttae}

The echinactinomyxon stage of $S$. truttae was released from Lumbriculus variegatus and on 2 occasions from individual Tubifex tubifex.

Over the 2 yr study period, the overall prevalence rate of the echinactinomyxon type released from the oligochaete host was $0.14 \%$. However, in 1996-1997 it was slightly lower than in 1997-1998 with prevalence rates of 0.12 and $0.17 \%$, respectively. Considering infection levels by season, the highest overall prevalence rate was found in spring (March-May) $(0.45 \%)$, followed by autumn (September-November) (0.04\%), winter (December-February) $(0.03 \%)$ and summer (June-August) $(0.03 \%)$. However, the prevalence rate of echinactinomyxon was at its highest on 4 May 1997 $(0.72 \%)$ in the first year and on 3 March $1998(0.80 \%)$ in the second year. In the rest of the sampling period the prevalence rates were very low (Fig. 4).

\section{Extrasporogonic stages of Sphaerospora truttae in naturally infected salmon}

Extrasporogonic stages were first detected in the blood of salmon at the beginning of July (4 July 1997) from the 1996/1997 cohort when the prevalence rate was $50 \%$. Subsequently, prevalence rates were 50 and $70 \%$ on 4 August 1997 and 6 September 1997, re- 

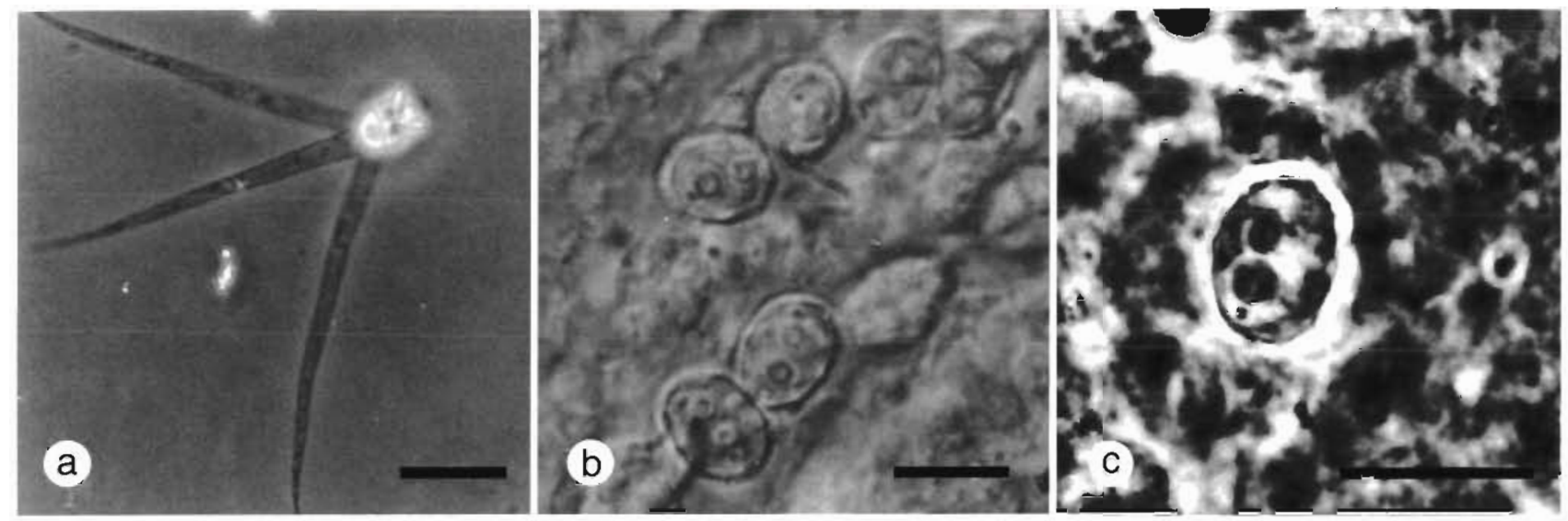

Fig. 2. (a) An echinactinomyxon spore released from Lumbriculus variegatus (scale bar $=10 \mu m$ ). (b) Sporogonıc stages oí Sphaerospora truttae obtained $3.5 \mathrm{mo}$ post-exposure to echinactinomyxon spores (scale bar $=10 \mu \mathrm{m}$ ). (c) Mature spore of S. truttae obtained 4.5 mo post-exposure to echinactinomyxon spores (scale bar $=12 \mu \mathrm{m}$ )

spectively, after which they were no longer found. Extrasporogonic stages were thus found only over an 8 to $10 \mathrm{wk}$ period from July to September (Fig. 4).

\section{DISCUSSION}

The life cycle of Sphaerospora truttae involves an echinactinomyxon type actinosporean released from the oligochaete Lumbriculus variegatus and, to a lesser extent, Tubifex tubifex.

No myxosporean species has been previously demonstrated to have a member of the collective group echinactinomyxon involved in its life cycle. The causative agent of proliferative gill disease (PGD) in channel catfish and Sphaerospora renicola in common carp are the only Sphaerospora species previously demonstrated to be transmitted via an oligochaete and these species have an aurantiactinomyxon and neo-

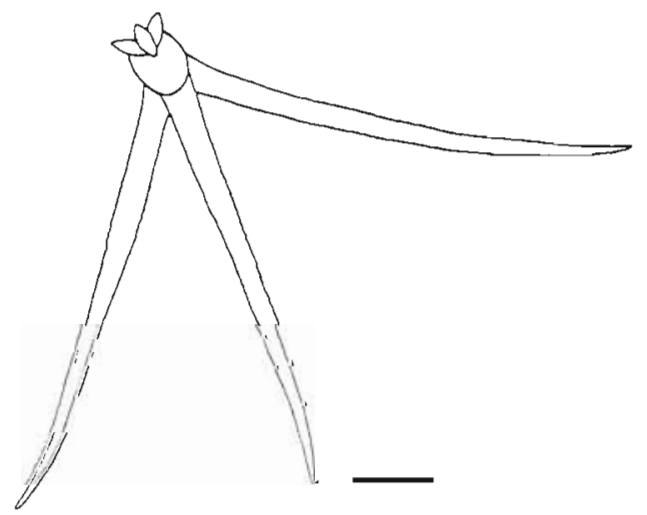

Fig. 3. Hand drawing of echinactinomyxon spore from Lumbriculus variegatus (scale bar $=10 \mu \mathrm{m}$ ) actinomyxum stage in their life cycles (Styer et al. 1991, Molnar et al. 1999).

The genus Hoferellus also belonging to the family Sphaerosporidae consists of 2 species, Hoferellus cyprini and $H$. carrassii, which have guyenotia and aurantiactinomyxon actinosporean stages, respectively, in their life cycle (El-Matbouli et al. 1992, Grossheider \& Körting 1992). Thus, the 5 species of the Sphaerosporidae in which the actinosporean stages have been identified have actinosporean stages belonging to 4 different collective groups of actinosporeans. This is difficult to interpret and will probably require the use of molecular techniques to determine affinities between and within groups of myxosporeans and actinosporeans.

The time taken for the completion of actinospore development in oligochaete worms and myxosporean de-

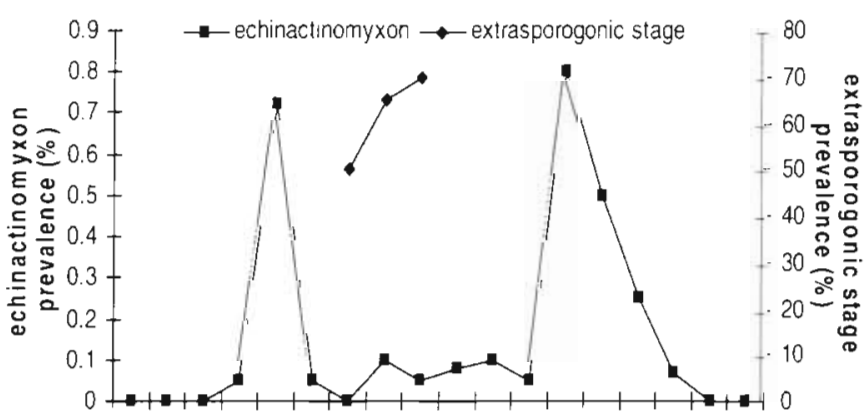

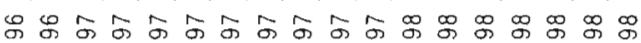

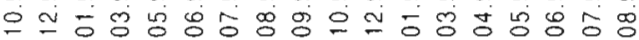

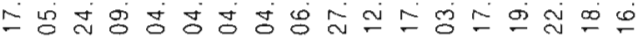

\section{Months}

Fig. 4. Prevalence rates of echinactinomyxons released from Lumbriculus variegatus and extrasporogonic stages of Sphaerospora truttae in Atlantic salmon from 17 October 1996 to $16 \mathrm{Au}$ gust 1998 (dates given as day/month/year) 
velopment in fish is generally negatively correlated with increasing water temperature, in most cases 3 to 4 mo is needed. Infections of salmon with sporogonic stages of Sphaerospora truttae were first seen at $3.5 \mathrm{mo}$ post-infection $(110 \mathrm{~d})$ in this study and mature S. truttae spores were observed at 4.5 mo post-infection (138 d) at 12 to $16^{\circ} \mathrm{C}$. The shortest experimental myxospore formation time in the literature is $60 \mathrm{~d}$ at $18^{\circ} \mathrm{C}$ for Myxidium giardi (Benajiba \& Marques 1993), and the longest is $169 \mathrm{~d}$ for Hoferellus cyprini at an unreported water temperature (Grossheider \& Körting 1992). Thus, the time taken for $S$. truttae to develop mature spores lies within the time range reported for other myxosporeans.

Experimental prevalence levels recorded in the literature are variable, ranging from 20\% (Benajiba \& Marques 1993) to $100 \%$ (El-Matbouli \& Hoffmann 1989, 1993, Yokoyama 1997). The experimental infection prevalence for Sphaerospora truttae was $50 \%$ over both experiments and thus within the range reported in the literature, although the number of fish used was relatively small.

The mean spore dimensions of Sphaerospora truttae obtained experimentally in this study and those reported in the literature (see McGeorge et al. 1996b) were very similar. Spore measurements obtained in this study from experimentally infected Atlantic salmon were slightly longer and wider than in those from naturally infected fish but the ranges of dimensions lay almost within the same minimum and maximum values. Similar results were also obtained by McGeorge et al. (1996b) from salmon experimentally infected by intraperitoneal injection of extrasporogonic stages of $S$. truttae and naturally infected fish.

The echinactinomyxon-type appears to be a new member of the collective group echinactinomyxon following the comparisons made with the other known species and types previously found (Janiszewska 1957. Marques 1984, Styer et al. 1992, Xiao \& Desser 1998a). It is the smallest echinactinomyxon type so far identified. The closest forms found in the literature with respect to spore dimensions were Echinactinomyxon astilum Janiszewska, 1964 and echinactinomyxon 'B' of Xiao \& Desser (1998a); however, the position of the polar capsules and the shape of the spore body in these types differed from the echinactinomyxon type used in these experiments.

The overall infection prevalence of the echinactinomyxon type was $0.14 \%$ over the 2 yr study period. Xiao \& Desser (1998b) reported 6 different echinactinomyxon types from a lake in Canada with overall prevalence rates between 0.03 and $0.34 \%$. There was some difference in the prevalence rate of the echinactinomyxon type in the 2 study years. Similarly, Yokoyama et al. (1993) found that the prevalence of an echinactinomyxon species in fish culture ponds in Japan was less than $1 \%$ in the first year of study and increased to $4.4 \%$ in the second year.

The echinactinomyxon type was mostly released in spring $(0.45 \%)$ and was much less abundant in the other seasons. Recent studies have also shown seasonal variations in the prevalence of oligochaete infections (Yokoyama et al. 1993, El-Mansy et al. 1998b,c, Xiao \& Desser 1998b). In the present study, the prevalence rate of echinactinomyxon was highest at the beginning of May in the first year of study and in the beginning of March in the second year and there was a single peak in the infection prevalence of the echinactinomyxon type each year, as observed by Yokoyama et al. (1993) for their echinactinomyxon type.

The present study showed that the Sphaerospora truttae myxosporean stage has an annual cycle with extrasporogonic and sporogonic stages in the fish. Extrasporogonic stages were first found at the beginning of July and were present for 8 to $10 \mathrm{wk}$. Examination of fish for $S$. truttae at the beginning of June was negative but very early stages of the parasite might not have been detected. McGeorge et al. (1996a) also observed similar dates for the first detection of the extrasporogonic stages of $S$. truttae and also showed that there was a pre-patent period of at least 2 to $4 \mathrm{wk}$ between when fish became infected and when that infection became detectable. Thus, infection of salmon with $S$. truttae occurs around the beginning of June in this environment.

Actinosporean stages of Sphaerospora truttae must therefore be released from the oligochaete host not later than May in order to infect the 0+ year class of salmon. The pre-patent period of 2 to $4 \mathrm{wk}$ was determined by McGeorge et al. (1996a) in fish from a farm in which water temperatures averaged between 10 to $12^{\circ} \mathrm{C}$ in March-May, whereas in this study temperatures were on average between 7 and $9^{\circ} \mathrm{C}$ in this period. Thus, it might be that the pre-patent period exceeded $4 \mathrm{wk}$ in the site studied here.

Echinactinomyxon spores were mostly released from March-May. The experimental infections described here did show that spores released before May are infective to fish. If spores were released naturally in March or April, then it might be expected that $0+$ fish would become infected at that time, which they apparently do not. It may be therefore that this early release observed is an artefact of laboratory conditions and that spores would not be released in the wild until May. A low prevalence of Lumbriculus variegatus were found to release echinactinomyxon in all seasons. It is not clear whether this also was an artefact or whether such a release would contribute to fish infections, although McGeorge et al. (1996b) found that once-infected Atlantic salmon seemed to be refractory to reinfection. 
This study has demonstrated that the life cycle of Sphaerospora truttae involves an echinactinomyxon stage released from Lumbriculus variegatus and Tubifex tubifex. The seasonal pattern of release of the echinactinomyxon stage fits closely with the period of infection of salmon with $S$. truttae although further work is needed to clarify the biology and development of the echinactinomyxon within the oligochaete host.

\section{LITERATURE CITED}

Bartholomew JL, Whipple MJ, Stevens DG, Fryer JL (1997) The life cycle of Ceratomyxa shasta, a myxosporean parasite of salmonids requires a freshwater polychaete as an alternate host. J Parasitol 83:859-868

Benajiba MH, Marques A (1993) The alteration of actinomyxidian and myxosporidian sporal form in the development of Myxidium giardi (parasite of Anguilla anguilla) through oligochaetes. Bull Eur Assoc Fish Pathol 13:100-103

Brinkhurst RO (1963) A guide for the identification of British aquatic Oligochaeta. Freshw Biol Assoc Sci Publ 22:1-52

El-Mansy A, Molnar K, Szekely C (1998a) Development of Myxobolus portucalensis Saraiva \& Molnar, 1990 (Myxosporea: Myxobolidae) in the oligochaete Tubifex tubifex (Muller). Syst Parasitol 41:95-103

El-Mansy A, Szekely C, Molnar K (1998b) Studies on the occurrence of actinosporean stages of fish myxosporeans in a fish farm of Hungary, with the description of triactinomyxon, raabeia, aurantiactinomyxon and neoactinomyxum types. Acta Vet Hung 46:259-284

El-Mansy A, Szekely C, Molnar K (1998c) Studies on the occurrence of actinosporean stages of myxosporeans in Lake Balaton, Hungary, with the description of triactinomyxon, raabeia and aurantiactinomyxon types. Acta Vet Hung 46:437-450

El-Matbouli M, Hoffmann RW (1989) Experimental transmission of two Myxobolus spp. developing bisporogeny via tubificid worms. Parasitol Res 75:461-464

El-Matbouli M, Hoffman RW (1993) Myxobolus carassii Klokacheva, 1914 also requires an aquatic oligochaete, Tubifex tubifex as an intermediate host in its life cycle Bull Eur Assoc Fish Pathol 13:189-192

El-Matbouli M, Fischer-Scherl T, Hoffmann RW (1992) Transmission of Hoferellus carassij Achmerov, 1960 to goldfish Carassius auratus via an oligochaete. Bull Euro Assoc Fish Pathol 12:54-56

Fischer-Scherl T, El-Matbouli M, Hoffmann RW (1986) A new Sphaerospora sp. in brown trout (Salmo trutta m. fario) in Germany. Bull Eur Assoc Fish Pathol 6:16-19

Grossheider G, Körting W (1992) First evidence that Hoferellus cyprini (Doflein, 1898) is transmitted by Nais sp. Bull Eur Assoc Fish Pathol 17:17-20

Janiszewska J (1955) Actinomyxidia. Morphology, ecology, history of investigation, systematics, development. Acta Parasitol Pol 2:405-437

Janiszewska J (1957) Actinomyxidia. II. New systematics, sexual cycle, description of new genera and species. Zool Pol 8:3-34

Kent ML, Whitaker DJ, Margolis L (1993) Transmission of Myxobolus arcticus Pugachev and Khokhlov, 1979, a myxosporean parasite of Pacific salmon, via a triactinomyxon from the aquatic oligochaete Stylodrilus heringianus (Lumbriculidae). Can J Zool 71:1207-1211
Lom J, McGeorge J, Feist SW, Morris D, Adams A (1997) Guidelines for the uniform characterisation of the actinosporean stages of parasites of the phylum Myxozoa. Dis Aquat Org 30:1-9

Markiw M. Wolf K (1983) Myxosoma cerebralis (Myxozoa: Myxosporea) etiologic agent of salmonid whirling disease requires tubificid worm. (Annelida: Oligochaete) in its life cycle. J Protozool 30:561-564

Marques A (1984) Contribution a la connaissence des Actinomyxidies: ultrastructure, cycle biologique, systematique. PhD thesis, Universite des Sciences et Techniques de Languedoc, Montpellier

McGeorge J, Sommerville C, Wootten R (1996a) The epizootiology of Sphaerospora truttae (Myxozoa:Myxosporea) infections of Atlantic salmon Salmo salar at freshwater smolt producing hatcheries in Scotland. Dis Aquat Org 26:33-41

McGeorge J, Sommerville C, Wootten R (1996b) Transmission experiments to determine the relationship between Sphaerospora sp. from Atlantic salmon, Salmo salar L. and Sphaerospora truttae (Fischer-Scherl, El-Matbouli \& Hoffmann, 1986), a revised species description for $S$. truttae. Folia Parasitol 43:107-116

McGeorge J, Sommerville C, Wootten R (1997) Studies of actinosporean myxozoan stages parasitic in oligochaetes from sediments of a hatchery where Atlantic salmon harbour Sphaerospora truttae infection. Dis Aquat Org 30: $107-119$

Molnar K, El-Mansy A, Szekely C, Baska F (1999) Experimental identification of the actinosporean stage of Sphaerospora renicola Dykova \& Lom, 1982 (Myxosporea: Sphaerosporidae) in oligochaete alternate hosts. J Fish Dis 22: $143-153$

Özer A (1999) Studies on actinosporeans (Phlyum: Myxozoa) from a salmon farm in northern Scotland, with special reference to the actinosporean and myxosporean stages of Sphaerospora truttae Fischer-Scherl, El-Matbouli and Hoffmann, 1986. PhD thesis, University of Stirling

Rudish S, El-Matbouli M, Hoffmann RW (1991) The role of tubificid worms as an intermediate host in the life cycle of Myxobolus pavlovskii (Akhmerov, 1954). Parasitol Res 77 : $663-667$

Styer EL, Harrison LR, Burtle G (1991) Experimental production of proliferative gill disease in channel catfish exposed to a myxozoan-infected oligochaete, Dero digitata. J Aquat Anim Health 3:288-291

Styer JL, Harrison LR, Burtle GJ (1992) Six new species of actinomyxids from Dero digitata. International workshop on myxosporeans. October 6-8, 1992. Ceske Budejovice (abstract only)

Szekely C, El-Mansy A, Molnar K, Baska F (1998) Development of Thelohanellus hovarkai and Thelohanellus nikolskii (Myxosporea:Myxozoa) in oligochaete alternate hosts. Fish Pathol 33:107-114

Troullier A, El-Matbouli M, Hoffmann RW (1996) A new look at the life cycle of Hoferellus carassii in goldfish (Carassius auratus auratus) and its relation to 'kidney enlargement. disease' (KED). Folia Parasitol 43:173-187

Uspenskaya AV (1995) Alteration of actinosporean and myxosporean phases in the life cycle of Zschokella nova (Myxozoa). J Euk Microbiol 42:665-668

Walter G, Odening K, Bockhardt I (1991) Sphaerospora truttae (Myxosporidia) bei Salmo trutta und Thymallus thymallus: Ortsnachweis in Thüringen und im Harz sowie bei der Äsche. Angew Parasitol 32:113-119

Xiao C, Desser SS (1998a) Actinosporean stage of myxozoan parasites of oligochaetes from Lake Sasajewun, Algonquin, Ontario: new forms of echinactinomyxon, neoactino- 
myxum, aurantiactinomyxon, guyenotia, synactinomyxon and antonactinomyxon. J Parasitol 84:1010-1019

Xiao C, Desser SS (1998b) The oligochaetes and their actinosporean parasites in Lake Sasajewun, Algonquin Park. Ontario. J Parasitol 84:1020-1026

Yokoyama $\mathrm{H}$ (1997) Transmission of Thelohonellus hovarkai Achmerov, 1960 (Myxosporea:Myxozoa) to common carp Cyprinus carpio through the alternate oligochaete host. Syst Parasitol 36:79-84

Yokoyama H, Ogawa K, Wakabayashi $\mathrm{H}$ (1991) A new collection method of actinosporeans-a probable infective stage of myxosporeans to fishes-from tubificids and

Editorial responsibility: Wolfgang Körting,

Hannover, Germany experimental infection of goldfish with the actinosporean Raabeia sp. Fish Pathol 28:133-138

Yokoyama H, Ogawa K, Wakabayashi H (1993) Involvement of Branchiura sowerbyi (Oligochaeta: Annelida) in the transmission of Hoferellus carassi (Myxosporea:Myxozoa), the causative agent of kidney enlargement disease (KED) of goldfish Carassius auratus. Fish Pathol 28:135-139

Yokoyama H, Ogawa K, Wakabayashi H (1995) Myxobolus cultus n. sp. (Myxosporea:Myxobolidae) in the goldfish Carassius auratus transformed from the actinosporean stage in the oligochaete, Branchiura sowerbyi. J Parasitol $81: 446-451$

Submitted: June 22, 1999; Accepted: October 9, 1999

Proofs received from author(s): February 2, 2000 